\title{
Differential Effects of Neurotrophic Factors on Neurotransmitter Development in the IMR-32 Human Neuroblastoma Cell Line
}

\author{
Eric D. Rabinovsky, ${ }^{1}$ Wei-Dong Le, ${ }^{1}$ and James L. McManaman ${ }^{1,2,3}$ \\ ${ }^{1}$ Wagner ALS Research Laboratory, Department of Neurology, ${ }^{2}$ Division of Neuroscience, and ${ }^{3}$ Program in Cell and \\ Molecular Biology, Baylor College of Medicine, Houston, Texas 77030
}

The human neuroblastoma cell line IMR-32 exhibits both cholinergic and adrenergic properties. We have used IMR-32 cells to study the effects of CDF (CAT development factor) and bFGF (basic fibroblast growth factor) on the development of neurotransmitter properties. CDF treatment increases CAT activity in a dose-dependent manner, independent of cell density. Time course studies show that there is a threefold increase in the specific CAT activity in IMR-32 cells treated with CDF for $6 \mathrm{~d}$. CDF does not, however, affect the level of tyrosine hydroxylase (TH) activity, or the rate of cell proliferation. bFGF, on the other hand, induces TH activity and decreases CAT activity in a dose-dependent manner. bFGF's effect on TH is enhanced by increasing cell density, while its reduction of specific CAT activity is independent of cell density. Time course studies show a 30-fold increase in TH activity per cell and $a$ threefold decrease in CAT activity per cell, after treatment with bFGF for $6 \mathrm{~d}$. In contrast to the effects of CDF, bFGF enhances cell proliferation in IMA-32 cells. Double-labeled immunofluorescence studies showed that $95 \%$ of the cells stain for CAT and $65 \%$ stain for TH following treatment with CDF and bFGF, respectively. When these factors are combined, approximately $75 \%$ of the cells express both CAT and TH, demonstrating that IMR-32 cells are bipotential with regard to neurotransmitter-associated enzyme expression. We also show that insulin-like growth factor I and NGF selectively induce CAT activity and cell proliferation, respectively, whereas epidermal growth factor has no effect. Thus, IMR-32 cells appear to be differentially responsive to distinct neurotrophic factors and also provide a model for studying the specific effects of neurotrophic factors on functional differentiation.

The functional maturation of neurons involves the acquisition of an efficient mechanism for the synthesis and release of neurotransmitters. Although the processes that regulate the development of functional phenotype are poorly understood, there is increasing evidence that target-derived factors may influence the choice of neurotransmitter phenotype (Patterson, 1978; Lan-

\footnotetext{
Received Apr. 18, 1991; revised Aug. 20, 1991; accepted Aug. 26, 1991.

This work was supported by Cephalon Inc. and grants from the NIH and the MDA to J.L.M. We thank Dr. J. L. Haverkamp for valuable discussions and Ms. Robin Clark for her excellent technical expertise. In addition, we thank Dr. H. Epstein for his comments on the manuscript and Ms. Erica McManaman for her assistance in preparing the manuscript. This is publication No. 8 from the Wagner ALS research laboratory.

Correspondence should be addressed to Dr. James McManaman, Department of Neurology, Baylor College of Medicine, Houston, TX 77030.

Copyright (C) 1992 Society for Neuroscience 0270-6474/92/120171-09\$05.00/0
}

dis and Keefe, 1983; Schotzinger and Landis, 1990) as well as the timing and level of neurotransmitter enzyme expression in neurons with an established phenotype (Vaca, 1988). In vitro experiments have shown that extracts of cholinergic and adrenergic target tissues contain substances that influence the development of these properties in PNS and CNS neurons (Patterson and Chun, 1974; Prochiantz et al., 1981; Swerts et al., 1983; Tomozawa and Appel, 1986; McManaman et al., 1988). Although a number of these factors have been isolated and identified (Thoenen and Barde, 1980; Barde et al., 1982; McManaman et al., 1988; Adler et al., 1989; Yamamori et al., 1989), their cellular and phenotypic specificities have not been well characterized.

Neuronal cell lines have been used previously to characterize the cellular and biochemical effects of neurotrophic factors $(\mathrm{Pa}-$ velic and Spaventi, 1987; Rydel and Greene, 1987; Schubert et al., 1987; Pollock et al., 1990). Furthermore, neuronal lines that express multiple neurotransmitter enzymes provide a means of characterizing and comparing the effects of specific neurotrophic factors on differential phenotypic expression. The IMR-32 human neuroblastoma cell line expresses both cholinergic and adrenergic neurotransmitter properties (Tumilowicz et al., 1970; Schlesinger et al., 1976; West et al., 1977; Thompson et al., 1982). This cell line has previously been used to study the effects of NGF and bFGF (basic fibroblast growth factor) on growth and morphological differentiation (Reynolds and Perez-Polo, 1981; Sonnenfeld and Ishii, 1982; Ludecke and Unsicker, 1990).

In the present studies, the IMR-32 cell line was used to characterize the phenotypic specificities of CDF (CAT development factor), a newly identified neurotrophic factor from skeletal muscle; bFGF; NGF; IGF-I (insulin-like growth factor I); and EGF (epidermal growth factor). CDF is a $22-24 \mathrm{kDa}$ acidic protein from rat skeletal muscle that has been shown to enhance CAT in both unfractionated and motoneuron-enriched cultures of embryonic rat spinal cord cells (McManaman et al., 1990). Recent studies have demonstrated that this factor also selectively rescues embryonic chick motoneurons from cell death in vivo (McManaman et al., 1990) and stimulates CAT expression in the human ncuroblastoma cell linc LA-N-2 (McManaman and Crawford, 1991). The biochemical properties of CDF distinguish it from other factors that influence the phenotypic properties of neurons, such as NGF; bFGF; IGF-I, -II, and -III; EGF; and LIF (leukemia inhibitory factor) (McManaman et al., 1988). CDF is further distinguished from CNTF (ciliary neurotrophic factor) based on differences in $\mathrm{pI}, \mathrm{N}$-terminal amino acid sequence (E. D. Rabinovsky, W.-D. Le, and J. L. McManaman, unpublished observations), and mRNA expression 


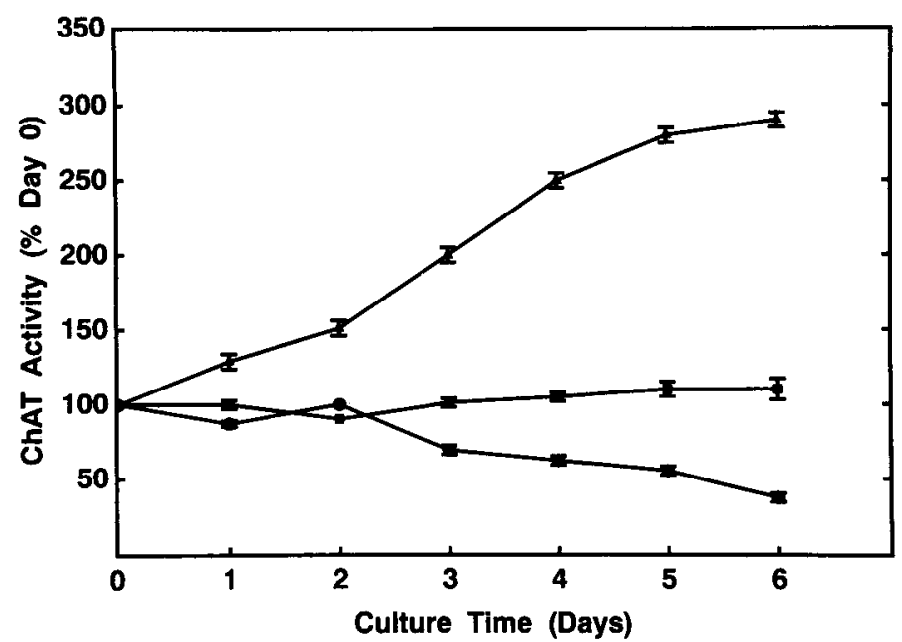

Figure 1. CDF and bFGF have opposite effects on CAT induction. IMR-32 cells were cultured with 5 nM CDF $(\Delta)$ or 3 nM bFGF $(\Theta)$, or without factors $(\square)$ and assayed for CAT activity on days $0-6$. The effects of these treatments on CAT activity (CAT/cell) are shown as the percentage of the day 0 CAT activity. Each value is the average $\pm \mathrm{SD}$ of triplicate culture wells.

in rat skeletal muscle (Stockli et al., 1989). NGF is the bestcharacterized neurotrophic factor and thus far the only factor with an established role in the expression of neurotransmitter properties (Thoenen and Barde, 1980; Vantini et al., 1989). NGF has been shown to enhance CAT expression in cultures of septai neurons (Hefti et al., 1985a; Knusel et al., 1990), tyrosine hydroxylase $(\mathrm{TH})$ expression in cultures of sympathetic neurons (Naujoks et al., 1982), and both CAT and TH in PC12 cells (Schubert et al., 1977; Hatanaka, 1981; Lee et al., 1985). bFGF, IGF-I, and EGF are best known as mitogenic growth factors (Carpenter and Cohen, 1976; Gospodarowicz et al., 1986; Mattsson et al., 1986). However, these factors also affect neurotransmitter phenotype and neuronal development. IGF-I increases CAT activity in rat septal cells (Knusel et al., 1990) and TH activity in chick dorsal root ganglia (Xue et al., 1988), whereas EGF induces TH activity and TH mRNA expression in the pheochromocytoma cell line PC-G2 (Goodman et al., 1980; Lewis and Chikaraishi, 1987) and CAT in PC-12 cells (McManaman and Crawford, 1991). bFGF induces CAT activity in rat septal cells (Knusel et al., 1990), rat spinal cord cultures (McManaman et al., 1989), and PC-12 cells (McManaman and Crawford, 1991). We have recently shown that CDF and bFGF have distinct and additive effects on the cholinergic properties of cultured embryonic spinal cord and the LA-N-2 human neuroblastoma cell line (McManaman et al., 1989; McManaman and Crawford, 1991).

In this study, we examine the effects of these factors on CAT and $\mathrm{TH}$ induction in a cell line that exhibits both cholinergic and adrenergic properties. Our findings demonstrate that the factors vary in their abilities to induce phenotypic changes and show that two of these factors (CDF and bFGF) have opposing effects on phenotypic expression within a single cell.

\section{Materials and Methods}

Dulbecco's Modified Eagle's Medium (DMEM), glutamine, penicillin, streptomycin, nonessential amino acids, and sodium pyruvate were purchased from GIBCO (Grand Island, NY). Trypsin and general chemicals were obtained from Sigma (St. Louis, MO). Fetal bovine serum (FBS) was purchased from Hyclone Labs (Logan, UT). ${ }^{3} \mathrm{H}$-acetyl-coenzyme
$\mathrm{A}(\mathrm{CoA})$ and ${ }^{3} \mathrm{H}$-thymidine were obtained from New England Nuclear (Boston, MA), and L-carboxyl- ${ }^{14} \mathrm{C}$-tyrosine was obtained from Amersham (Arlington Heights, IL). Plastic culture plates were obtained from Costar (Cambridge, MA). Mouse monoclonal antibody to CAT was purchased from Chemicon (Temecula, CA), and rabbit anti-tyrosine hydroxylase was purchased from Eugene Tech International (Allendale, NJ). Biotinylated goat anti-mouse IgG, goat anti-rabbit fluorescein isothiocyanate (FITC), and streptavidin-Texas red were purchased from Jackson ImmunoResearch (Westgrove, PA). NGF was a generous gift from professor J. R. Perez-Polo (University of Texas Medical Branch, Galveston, TX). IGF-I was obtained from Amgen (Thousand Oaks, CA), and EGF was obtained from Collaborative Research (Bedford, MA). bFGF was a gift from Dr. F. F. Fuller, California Biotechnology Inc. (Mt. View, CA). IMR-32 cells were obtained from American Type Culture Collection (Rockville, MD).

Cell culture. IMR-32 cells were plated at a density of $10^{4} \mathrm{cells} / \mathrm{well}$ in poly-L-lysine-coated 96-well culture plates in DMEM supplemented with $10 \%$ FBS, penicillin $(50 \mathrm{IU} / \mathrm{ml})$, streptomycin $(50 \mu \mathrm{g} / \mathrm{ml}), 2 \mathrm{~mm}$ glutamine, $1 \mathrm{~mm}$ nonessential amino acids, and $1 \mathrm{~mm}$ sodium pyruvate. The cultures were maintained at $37^{\circ} \mathrm{C}$ in a humidified atmosphere of $5 \% \mathrm{CO}_{2}, 95 \%$ air. Growth factors were added to the cultures at indicated concentrations at the time of plating. Unless otherwise indicated, half the media was removed and replaced with fresh media and growth factor after $3 \mathrm{~d}$ of incubation. Plates were assayed for CAT, $\mathrm{TH},{ }^{3} \mathrm{H}$-thymidine uptake, and cell growth at given times as described below.

Cell proliferation and mitogenic activity. Cell proliferation was determined by directly counting single cell suspensions obtained by removing all media and treating each well with $25 \mu 1$ of $0.2 \%$ trypsin, $0.02 \%$ EDTA in Hank's Balanced Salt Solution. After 1 min, cells were triturated, 125 $\mu 1$ of culture media were added, and viable cells were counted by trypan blue exclusion. The viability of cells under these conditions was routinely $>90 \%$. For ${ }^{3} \mathrm{H}$-thymidine incorporation experiments, $2 \times 10^{4}$ cells were cultured for $24 \mathrm{hr}$ in DMEM-10\% FBS, washed three times, and incubated for $24 \mathrm{hr}$ in defined serum-free media [DMEM containing transferrin $(100 \mathrm{mg} / \mathrm{ml})$, putrcscinc $(100 \mu \mathrm{m})$, selcnium $(30 \mathrm{~nm})$, progesterone $(20 \mathrm{~nm})$, and insulin $(2.5 \mu \mathrm{g} / \mathrm{ml})]$. The cells were then washed and refed with serum-free media, incubated with factors for $24 \mathrm{hr}$, and pulsed with ${ }^{3} \mathrm{H}$-thymidine $(0.2 \mu \mathrm{Ci} /$ well $)$ for $1 \mathrm{hr}$. The amount of ${ }^{3} \mathrm{H}-$ thymidine incorporated by the cells was determined in a liquid scintillation counter after harvesting the cells onto glass fiber filters with a Brandl Harvester (Gaithersburg, MD). The level of ${ }^{3} \mathrm{H}$-thymidine uptake was then normalized to the number of cells that excluded trypan blue in identically treated sister cultures.

CAT activity. Choline acetyltransferase activity in extracts of IMR32 cells was determined by a modification of the method of Fonnum (1969), measuring the formation of ${ }^{3} \mathrm{H}$-acetylcholine from ${ }^{3} \mathrm{H}$-acetylCoA and unlabeled choline, as previously described for spinal cord cultures (McManaman et al., 1988). The reaction solution contained $0.1 \% \mathrm{NP}-40,5 \mathrm{~mm} \mathrm{NaH} \mathrm{PO}_{4}, 150 \mathrm{~mm} \mathrm{NaCl}, 10 \mathrm{~mm}$ EDTA, $1.5 \mathrm{~mm}$ choline chloride, $0.1 \mathrm{~mm}$ eserine sulfate, $0.5 \mathrm{mg} / \mathrm{ml}$ bovine serum albumin, and $0.1 \mathrm{~mm}{ }^{3} \mathrm{H}$-acetyl-CoA (specific activity, $32 \mu \mathrm{Ci} / \mu \mathrm{mol}$ ). Naphthylvinyl pyridine was used to verify that the acetyltransferase activity was due to CAT and not the result of nonspecific acetyltransferase activity (Cavallito et al., 1970). CAT activity was normalized to cell number by dividing the amount of ${ }^{3} \mathrm{H}$-acetylcholine synthesized per well by the number of cells in identically treated sister cultures.

Tyrosine hydroxylase. Tyrosine hydroxylase activity was determined by a coupled nonenzymatic decarboxylation of ${ }^{14} \mathrm{C}$-L-dopa, formed from ${ }^{14} \mathrm{C}-\mathrm{L}$-tyrosine (Okuno and Fujisawa, 1983), as modified for 96-well culture plates (Bostwick and Le, 1991). Briefly, the medium was removed and the cells were solubilized by adding $25 \mu 1$ of $50 \mathrm{~mm}$ Tris$\mathrm{HCl}, \mathrm{pH} 7.4$, containing $0.2 \%$ Triton $\mathrm{X}-100$, to each well and incubating for $30 \mathrm{~min}$ on ice. The reaction was initiated by adding $16.6 \mu \mathrm{l}$ of icecold $0.45 \mathrm{M}$ 2-[N-morpholino]ethanesulfonic acid, $\mathrm{pH} 6.2,2500 \mathrm{U}$ of catalase, $2.3 \mathrm{~mm}$ dithiothreitol, $4.7 \mathrm{~mm}$ ascorbic acid, $2.3 \mathrm{~mm}$ 6- $\mathrm{MePtH}_{4}$, and $96 \mu \mathrm{M}{ }^{14} \mathrm{C}$-tyrosine $(54.8 \mathrm{mCi} / \mathrm{mmol})$ to each well and incubating at $37^{\circ} \mathrm{C}$ for $20 \mathrm{~min}$. The decarboxylation was then initiated by the addition of $41.6 \mu \mathrm{l}$ of $16.5 \mathrm{~mm}$ potassium ferricyanide and $10 \mathrm{~mm}$ $p$-chloromecuribenzenesulfonic acid in $50 \mathrm{~mm}$ Tris, $\mathrm{pH}$ 8.0. The released ${ }^{14} \mathrm{C}-\mathrm{CO}_{2}$ was adsorbed onto Whatman \#3 filter paper pretreated with methylbenzethonium hydroxide. After cooling, the adsorbed radioactivity was determined in a liquid scintillation counter. The amount of TH activity was normalized to cell number as described above for CAT activity. All TH activity is reported as the amount of ${ }^{14} \mathrm{C}$-tyrosine hydrolyzed $/ 1 \mathrm{hr} /$ cell. 


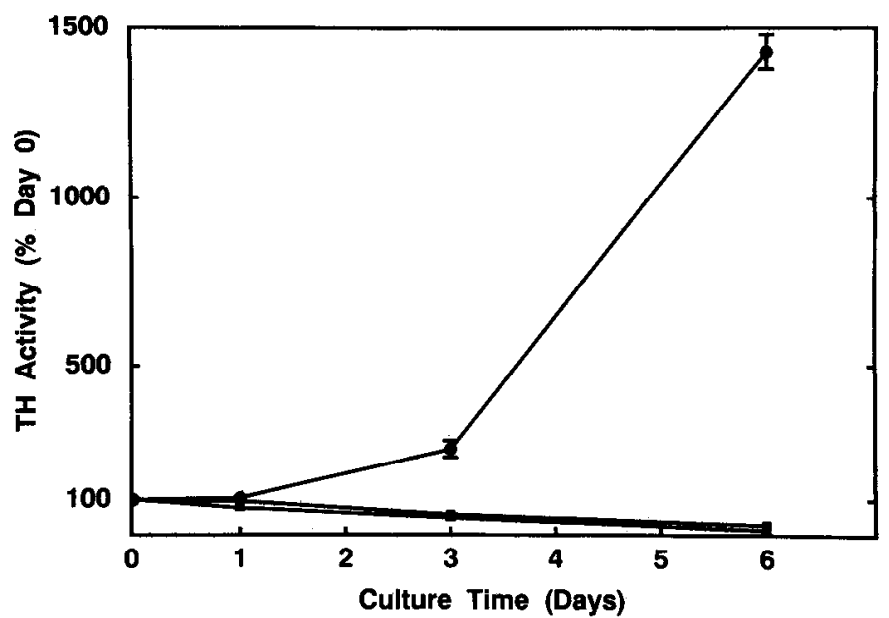

Figure 2. bFGF but not CDF specifically induces TH activity. IMR32 cells were cultured with $5 \mathrm{nM} \operatorname{CDF}(\Delta)$ or $3 \mathrm{nM} \mathrm{bFGF}(\bullet)$, or without factors $(\square)$ and assayed for TH activity on days $0-6$. The effects of these treatments on specific TH activity (TH/cell) are shown as the percentage of day $0 \mathrm{TH}$ activity. Each value is the average $\pm \mathrm{SD}$ of triplicate culture wells.

Immunofluorescence. IMR-32 cells were plated in DMEM-10\% FBS at a density of $2.5 \times 10^{4}$ cells on poly-L-lysine $(5 \mathrm{mg} / \mathrm{ml})$ treated glass coverslips $(12 \mathrm{~mm})$ placed in 24-well plates. Factors were added at the time of plating and again every other day of culture. After 10-12 d, the coverslips were washed in PBS, fixed in 4\% paraformaldehyde for 15 min, washed with PBS, and then permeabilized by incubating in $1 \%$ Triton X-100, 2\% goat serum in PBS, for $2 \mathrm{hr}$. The cultures were then incubated with monoclonal antibody to CAT or polyclonal antibody to TH antibodies (diluted 1:100 and 1:1000, respectively, in $1 \%$ goat serum, $0.05 \%$ Tween 20 ) overnight at $4^{\circ} \mathrm{C}$, washed in PBS containing $0.05 \%$ Tween 20 , and incubated with biotinylated goat anti-mouse IgG (diluted 1:300 in 1\% goat serum, $0.05 \%$ Tween 20 ) for $1 \mathrm{hr}$. The coverslips were washed and incubated with streptavidin-Texas red $(1: 300)$ or FITC-conjugated goat anti-rabbit IgG (diluted 1:200 in 1\% goat serum, $0.05 \%$ Tween 20 ) for $30 \mathrm{~min}$, rinsed, and mounted in $90 \%$ glycerol. The number of immunoreactive cells was quantified by counting 300 cells per slide in triplicate, at $200 \times$ or $400 \times$ power using a Nikon Optiphot fluorescent microscope.

Growth factor activities. Preliminary dose-response experiments were performed to verify the activities of bFGF, CDF, EGF, NGF, and IGF1 . The activities of bFGF, EGF, and IGF-1 were verified by their ability to enhance ${ }^{3} \mathrm{H}$-thymidine proliferation in $3 \mathrm{~T} 3$ fibroblasts (McManaman et al., 1989). The activity of NGF was verified by its ability to increase neurite outgrowth in PC-12 cells (Green and Ruckenstein, 1989). CDF's activity was detcrmined by its ability to cnhance CAT activity in cmbryonic day 14 (E14) rat spinal cord cultures (McManaman et al., 1988).

\section{Results}

\section{$C D F$ and $b F G F$ differentially affect $C A T$ and $T H$ activity in IMR -32 cells}

IMR-32 cells contain low but detectable basal levels of CAT activity that increase in direct proportion to cell number during culture. When basal CAT activity is normalized to cell number, the average (three separate experiments) specific CAT activity (CAT/cell) of control cells $(0.14 \pm 0.01 \mathrm{fmol} / \mathrm{hr} / \mathrm{cell})$ remains constant over the culture period (Fig. 1). The addition of CDF increases the specific CAT activity to $0.28 \pm 0.018 \mathrm{fmol} / \mathrm{hr} / \mathrm{cell}$ $(N=3)$ after $3 \mathrm{~d}$ and $0.420 \pm 0.035 \mathrm{fmol} / \mathrm{hr} / \mathrm{cell}(N=3)$ after $6 \mathrm{~d}$ of culture. In contrast, the addition of $\mathrm{bFGF}$ decreases the specific CAT activity of IMR-32 cells to $0.09 \pm 0.01 \mathrm{fmol} / \mathrm{hr} /$ cell $(N=3)$ after $3 \mathrm{~d}$ and $0.029 \mathrm{fmol} / \mathrm{hr} /$ cell $(N=3)$ after $6 \mathrm{~d}$ of culture.
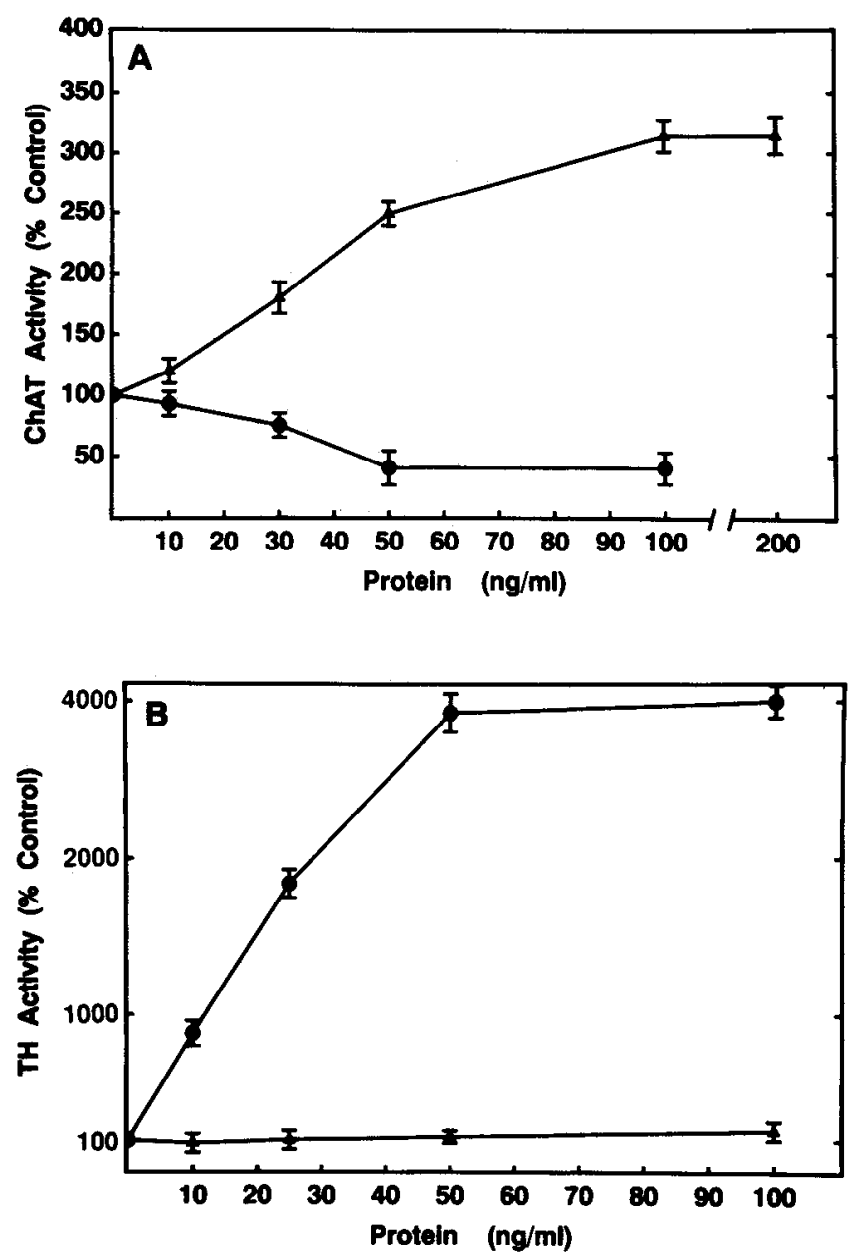

Figure 3. The effects of CDF and bFGF are dose dependent. IMR-32 cells were cultured with CDF $(\Delta)$ or bFGF ( $(\bullet)$ for $6 \mathrm{~d}$ at the given concentrations $(\mathrm{ng} / \mathrm{ml})$. The effects of these treatments on CAT activity $(\mathrm{CAT} / \mathrm{cell})(A)$ and TH activity (TH/cell) $(B)$ are shown as percentages of control values. Each value is the average \pm SD of triplicate culture wells.

As shown in Figure 2, the specific TH activity (TH/cell) of IMR-32 cultures treated with CDF remains identical to that of control cells throughout the culture period. On the other hand, bFGF markedly enhances the development of TH in IMR-32 cells. In cultures treated with bFGF for $3 \mathrm{~d}$, the average specific TH activity was $0.11 \pm 0.01 \mathrm{fmol} / \mathrm{hr} / \mathrm{cell}(N=3)$ compared to $0.05 \perp 0.009 \mathrm{fmol} / \mathrm{hr} / \mathrm{cell}(N=3)$ for controls. After $6 \mathrm{~d}$ of culture, the specific $\mathrm{TH}$ activity of bFGF-treated cells increased to $0.75 \pm 0.08 \mathrm{fmol} / \mathrm{hr} / \mathrm{cell}(N=3)$, while that of control and CDF-treated cells decreased to $0.03 \pm 0.008 \mathrm{fmol} / \mathrm{hr} / \mathrm{cell}(N=$ 3).

\section{The effects of $C D F$ and $b F G F$ are dose dependent}

The effects of both CDF and bFGF on CAT activity are dose dependent (Fig. $3 A$ ). After $6 \mathrm{~d}$ of treatment, the mean $(N=3)$ half-maximal effect of CDF on CAT specific activity was 11.0 $\pm 2.5 \mathrm{ng} / \mathrm{ml}(0.5 \mathrm{nM})$, while that of bFGF was $25.1 \pm 3.8 \mathrm{ng} /$ $\mathrm{ml}(1.4 \mathrm{~nm})$. The effect of bFGF on TH activity is also dose dependent. As shown in Fig. $3 B$, the mean $(N=3)$ half-maximal effect of bFGF TH specific activity was $21.9 \pm 4.6 \mathrm{ng} / \mathrm{ml}(1.2$ $\mathrm{nM})$, which is comparable to the half-maximal dose required to decrease CAT activity. 

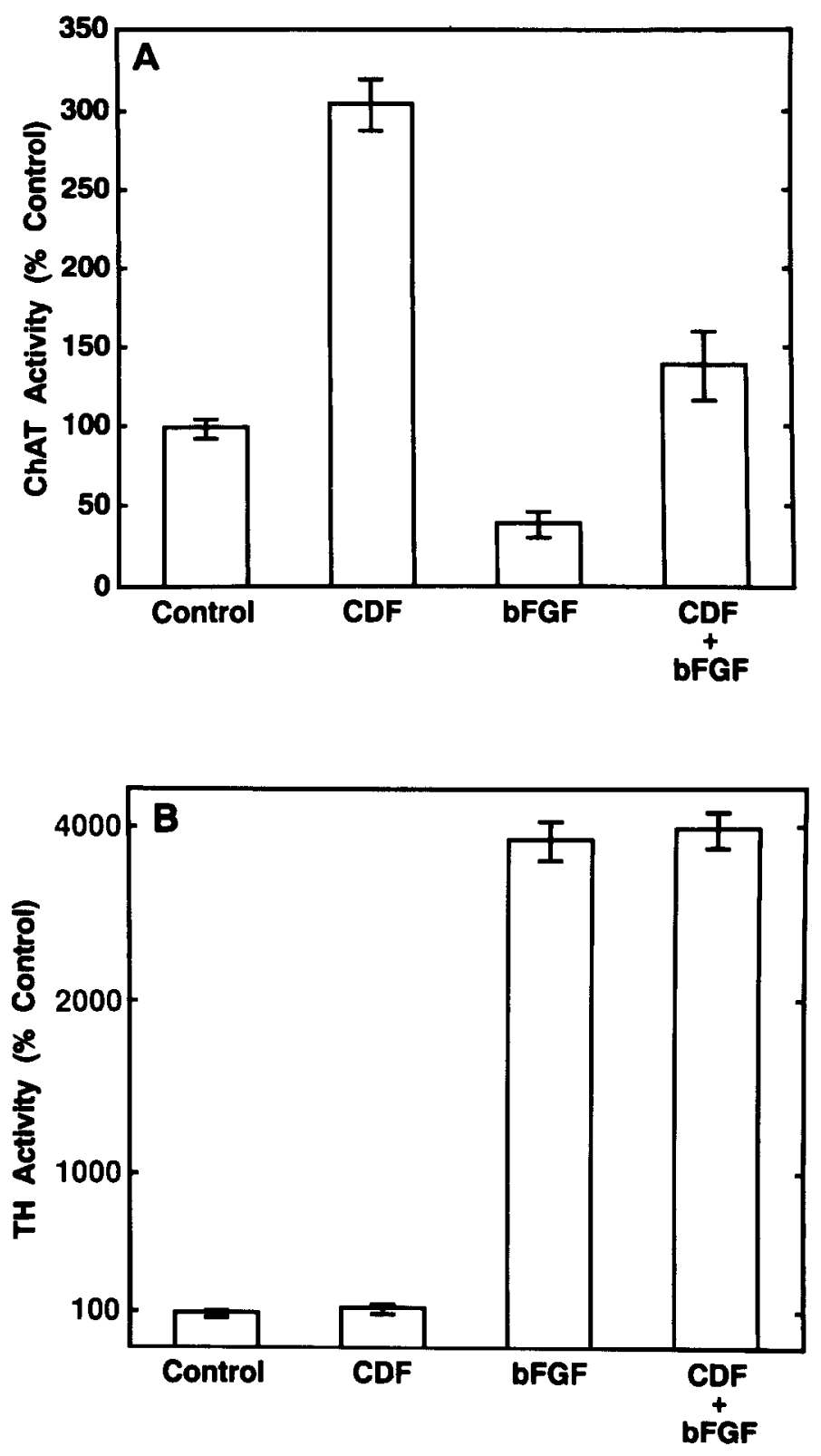

Figure 4. The actions of CDF and bFGF on CAT and TH activity are separate. The combined effects of CDF and bFGF were determined by treating IMR-32 cells with saturating amounts of CDF $(5 \mathrm{nM})$ or bFGF ( $3 \mathrm{nM}$ ) alone, or in combination with each other. The effects of these treatments on CAT activity (CAT/cell) $(A)$ and TH activity (TH/cell) $(B)$ are shown as percentages of control values. Each value is the average $\pm \mathrm{SD}$ of triplicate culture wells.

\section{Cell density differentially affects the actions of} $b F G F$ and $C D F$

The influence of cell density on the actions of CDF and bFGF was determined by treating cells plated at $1,2.5,5$, and $10 \times$ $10^{4}$ cells/well with saturating amounts of CDF or bFGF and assaying for CAT or TH after $3 \mathrm{~d}$. After this period in culture, luw-density cultures ( 1 and $2 \times 10^{4}$ cells/well) were still in log phase, while high-density cultures ( 5 and $10 \times 10^{4}$ cells/well) were confluent (data not shown). As shown in Table 1, cell density does not influence CDF's effect on CAT. At all plating densities, CDF increased CAT activity approximately twofold over control cultures. By comparison, cell density has mixed effects on bFGF's actions. There was no effect of cell density on the bFGF-mediated decrease in CAT activity. In both low and high density cultures, bFGF decreased the CAT specific activity to the same extent (Table 1). In contrast, the effect of bFGF on TH specific activity was markedly enhanced in high-density cultures.

\section{$C D F$ and $b F G F$ do not affect each other's actions}

The above experiments demonstrate that CDF and bFGF differentially affect CAT and TH development in IMR-32 cells. To determine if the action of one factor affects that of the other, IMR-32 cells were treated simultaneously with saturating amounts of both factors and assayed for CAT and TH activity after $6 \mathrm{~d}$ of culture. As shown in Figure 4, the bFGF-mediated decrease in CAT specific activity is the same for both control and CDF-treated cultures $(34.5 \% \pm 5.2$ in control cultures and $38.1 \% \pm 6.5$ in CDF-treated cultures). In accordance with this result, CDF does not interfere with bFGF's effect on TH (Fig. $4 B)$.

\section{IMR-32 cells differentially express $C A T$ and $T H$ in response to $C D F$ and $b F G F$}

The effects of CDF and bFGF on the expression of CAT and TH in IMR-32 cells were also analyzed by double-label immunofluorescence (Fig. 5). Cultures treated with CDF are CAT positive but not $\mathrm{TH}$ positive. Conversely, cultures treated with bFGF are TH positive but not CAT positive. The number of cells exhibiting positive reaction with either antibody is quantified in Table 2. In control cultures, less than $10 \%$ of the cells were positive for either CAT or TH. Following CDF treatment, however, nearly all of the cells were CAT positive, but fewer than $10 \%$ expressed detectable TH immunoreactivity. In contrast, in cultures treated with bFGF the majority of the cells were positive for TH, while the number of CAT-positive cells was identical to controls. To determine if a single cell is capable of expressing both CAT and TH, IMR-32 cultures were simultaneously treated with CDF and bFGF. Because bFGF treatment decreases the specific CAT activity of the cells, it was necessary to prolong treatment with the factors for $12 \mathrm{~d}$. In agreement with the results obtained with $6 \mathrm{~d}$ cultures, untreated cells did not express detectable CAT or TH immunoreactivity (data not shown). However, following combined treatment with $\mathrm{CDF}$ and bFGF, $75.9 \% \pm 10.7(N=3)$ of the cells were reactive with both antibodies (Figure 6).

\section{$C D F$ and $b F G F$ differ in their effects on cellular proliferation and ${ }^{3} \mathrm{H}$-thymidine incorporation into IMR-32 cells}

The effects of growth factors on cell proliferation and ${ }^{3} \mathrm{H}$-thymidine incorporation are summarized in Table 3 . In serumcontaining medium, IMR-32 cells have a doubling timc of 35 $\mathrm{hr}$. The addition of CDF does not affect this growth rate, nor does it alter the level of ${ }^{3} \mathrm{H}$-thymidine incorporation in serumfree media. In contrast, the addition of bFGF both decreases the doubling time of IMR-32 cells in serum-containing media to $24 \mathrm{hr}$ and stimulates ${ }^{3} \mathrm{H}$-thymidine incorporation in serumfree media by $50 \%$ over controls.

\section{The effects of NGF, IGF-I, and EGF differ from} those of $C D F$ and $b F G F$

IMR-32 cells were also treated with NGF, IGF-I, and EGF for $6 \mathrm{~d}$ and assayed for CAT and TH activity (Fig. $7 A, B$ ). IGF-I treatment produced a small increase in the average $(N=3)$ 
Table 1. Effects of cell density on CDF and bFGF induction of CAT and TH activity

\begin{tabular}{|c|c|c|c|c|}
\hline \multirow{2}{*}{$\begin{array}{l}\text { Plating } \\
\text { density } \\
\text { (cells/well) }\end{array}$} & \multicolumn{2}{|l|}{$\begin{array}{l}\text { CAT activity } \\
\text { (\% control) }\end{array}$} & \multicolumn{2}{|l|}{$\begin{array}{l}\text { TH activity } \\
\text { (\% control) }\end{array}$} \\
\hline & $\mathrm{CDF}$ & bFGF & $\overline{\mathrm{CDF}}$ & bFGF \\
\hline $1.0 \times 10^{4}$ & $225.6 \pm 15.9$ & $63.8 \pm 6.8$ & $112.5 \pm 6.8$ & $225.5 \pm 9.5$ \\
\hline $2.5 \times 10^{4}$ & $215.9 \pm 17.6$ & $61.5 \pm 7.9$ & $101.3 \pm 10.6$ & $465.9 \pm 12.3$ \\
\hline $5.0 \times 10^{4}$ & $235.1 \pm 10.6$ & $68.1 \pm 5.3$ & $98.9 \pm 5.9$ & $895.3 \pm 25.1$ \\
\hline $10.0 \times 10^{4}$ & $201.4 \pm 10.4$ & $60.4 \pm 8.1$ & $108.3 \pm 8.7$ & $969.2 \pm 49.6$ \\
\hline
\end{tabular}

The levels of CAT and TH activity are shown as the percentage of the activity in control cultures. Each value is the average \pm SD from two separate experiments in which triplicate culture cells were treated with 5 nM CDF and 3 nM bFGF and assayed after $3 \mathrm{~d}$. The basal levels of CAT and TH activity per cell did not significantly change during the culture period.

specific CAT activity $(0.20 \pm 0.02 \mathrm{fmol} / \mathrm{hr} / \mathrm{cell})$ but did not affect TH specific activity. The effect of IGF-I on CAT activity is dose dependent with a mean half-maximal activity at $2 \mathrm{nM}$. In contrast, NGF and EGF, in concentrations ranging from 0.5 to $50 \mathrm{~nm}$, did not affect either CAT or TH activity. The effects of these various factors on the proliferation of IMR-32 cells are shown in Table 3. Similar to the effects of bFGF, NGF treatment produced a small increase in cell proliferation and ${ }^{3} \mathrm{H}$-thymidine incorporation. In contrast, there was no effect of IGF-I, EGF, or CDF on cell number or thymidine incorporation.

\section{Discussion}

It is well known that certain neurons are capable of expressing more than one transmitter phenotype. It may be that at certain stages of development, neurons are multipotential in this regard, until transmitter choice is determined by some environmental cue. The experiments described here demonstrate that two identified, naturally occurring molecules can differentially regulate a neuronal cell line to adopt one or another mode of transmitter expression. CDF, a $22 \mathrm{kDa}$ protein isolated from muscle that affects cholinergic development in vitro and rescues motoneurons in vivo, specifically induces CAT development in IMR-32 cells but does not affect TH. Basic. FGF is a ubiquitous $18 \mathrm{kDa}$ mitogenic growth factor with neuroactive effects on a number of neuronal subtypes in vivo and in vitro. In contrast to $\mathrm{CDF}$, bFGF specifically induces TH and decreases CAT in IMR-32 cells. Those IMR-32 cells that express CAT and/or TH do not constitute separate subpopulations of cells. Thus, the opposing effects of CDF and bFGF are most likely due to the differential regulation of neurotransmitter expression within a single bipotential cell type.

While CDF and bFGF enhance the expression of either CAT and $\mathrm{TH}$, respectively, as is apparent from immunofluorescence

Table 2. Number of CAT and TH-immunoreactive cells in IMR-32 cultures treated with CDF or bFGF

\begin{tabular}{lrr} 
& \multicolumn{2}{c}{ Number of cells (\% positive) } \\
\cline { 2 - 3 } Treatment & \multicolumn{1}{c}{ CAT } & \multicolumn{1}{c}{ TH } \\
\hline Control & $7.9 \pm 2.5$ & $5.1 \pm 2.3$ \\
CDF & $95.1 \pm 4.1$ & $4.2 \pm 1.5$ \\
bFGF & $2.5 \pm 1.9$ & $65.8 \pm 5.5$
\end{tabular}

Cells were treated with $5 \mathrm{nM}$ CDF or $3 \mathrm{nM}$ bFGF for $10 \mathrm{~d}$. Values are expressed as the percentage of cells that are positive for either CAT or TH as determined by double-label immunofluorescence. Each value is the average \pm SD of the two experiments. Individual experimental averages were obtained from counting 300 cells per slide in triplicate. studies, we do not yet know if these increases reflect actions at transcriptional or translational levels. Furthermore, there have been reports suggesting that the activities of both CAT and TH can be increased by posttranslational modifications (Rydel and Greene, 1987; Casper and Davies, 1989). Although we cannot directly rule out the possibility that in addition to increasing protein levels, CDF and bFGF may alter enzyme activities, neither agent has produced acute effects on CAT or TH activities. Thus, it is unlikely that CDF or bFGF alters the enzymatic activities of CAT or TH.

While the actions of CDF appear to be specific for CAT expression, bFGF appears to affect both CAT and TH expression. Similar to its effect on TH, bFGF's effects on CAT activity increase over time. Therefore, it is unlikely that bFGF directly inhibits this enzyme. bFGF also does not appear to interfere directly with CDF's induction of CAT, since the percentage reduction of CAT activity is the same in the presence or the absence of CDF stimulation. However, we cannot exclude the possibility that bFGF may interfere with CDF's actions. Finally, it would appear that bFGF's effects on CAT are separate and distinct from its effects on $\mathrm{TH}$. This conclusion is supported by both (1) the different time courses of bFGF's effects and (2) the differential influence of cell density on bFGF's actions on $\mathrm{TH}$ and CAT.

Factors that induce the expression of CAT while decreasing the expression of TH have previously been identified. For example, LIF, MANS (membrane-associated neurotrophic factor), and CNTF all enhance the expression of CAT and decrease TH expression in sympathetic neurons (Saadat et al., 1989; Rao et

Table 3. The effects of CDF, bFGF, NGF, IGF-I, and EGF on cell proliferation and ${ }^{3} \mathrm{H}$-thymidine uptake

\begin{tabular}{lcl} 
Treatment & Cell number & $\begin{array}{l}{ }^{3} \mathrm{H}-\text { Thymidine } \\
\text { incorporation }\end{array}$ \\
\hline Control & 100 & 100 \\
CDF & $98.5 \pm 5.4$ & $100.9 \pm 9.8$ \\
bFGF & $160.9 \pm 14.1$ & $151.5 \pm 17.5$ \\
NGF & $161.5 \pm 17.5$ & $157.4 \pm 18.9$ \\
IGF-I & $110.9 \pm 12.2$ & $108 \pm 12.5$ \\
EGF & $108 \pm 10.5$ & $110 \pm 8.1$
\end{tabular}

Cells preincubated in serum-free media were treated with factors for $24 \mathrm{hr}$ and then pulsed with ${ }^{3} \mathrm{H}$-thymidine for $1 \mathrm{hr}$. The changes in cell number and the levels of ${ }^{3} \mathrm{H}$-thymidine incorporation are shown as the percentage of control values. Each value is the average \pm SD from three separate experiments in which triplicate culture wells were treated with 5 nM CDF, 3 nM bFGF, 20 nM NGF, 10 nM IGFI, or $50 \mathrm{nM}$ EGF 


\section{CDF}
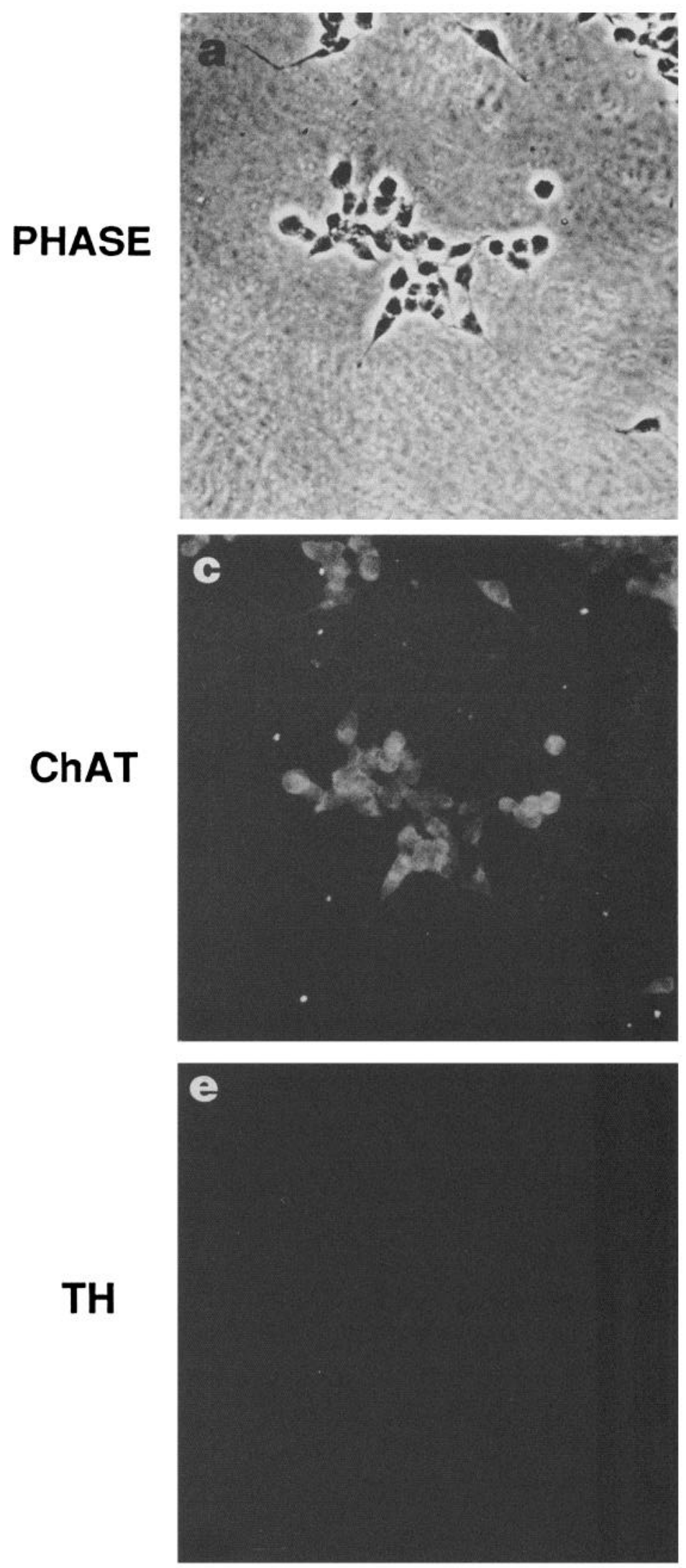

Figure 5. Expression of CAT and TH in response to CDF and bFGF. IMR-32 cells were treated with 5 nM CDF ( $a, c, e)$ or 3 nM bFGF ( $b, d$, $f$ ) for $10 \mathrm{~d}$ and then reacted simultaneously with monoclonal antibody to CAT and polyclonal antibody to TH. Cells were visualized under phase contrast $(a, b)$ and by fluorescence with anti-CAT $(c, d)$ and anti-TH $(e, f)$ and photographed at $200 \times$. 


\section{CDF / bFGF}

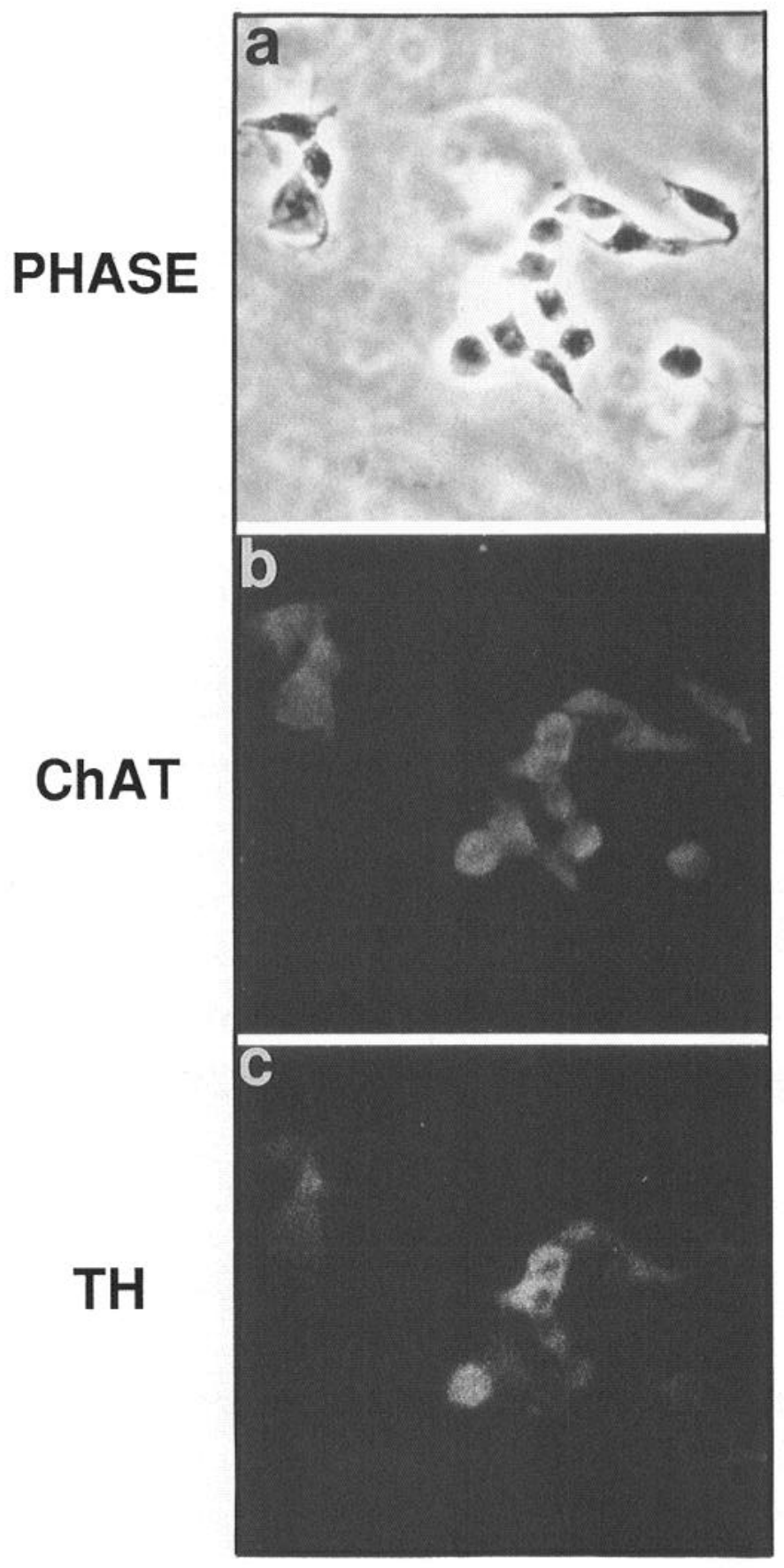

Figure 6. Dual expression of CAT and TH in response to CDF and bFGF. IMR-32 cells were treated with both $5 \mathrm{~nm}$ CDF and $3 \mathrm{~nm}$ bFGF $(a-c)$ for $12 \mathrm{~d}$ and then reacted simultaneously with monoclonal antibody to CAT and polyclonal antibody to TH. Cells were visualized under phase contrast $(a)$ and by fluorescence with anti-CAT $(b)$ and anti-TH $(c)$. CAT- and TH-positive cells were not detected in untreated cultures (not shown). Slides were photographed at $400 \times$.

al., 1990). On the other hand, although factors in neural tubeconditioned media enhance adrenergic expression and suppress cholinergic expression in neural crest cells (Howard and Bronner-Fraser, 1986), the identities of these agents have not been established. Our results provide the first demonstration of a purified growth factor increasing $\mathrm{TH}$ activity and decreasing
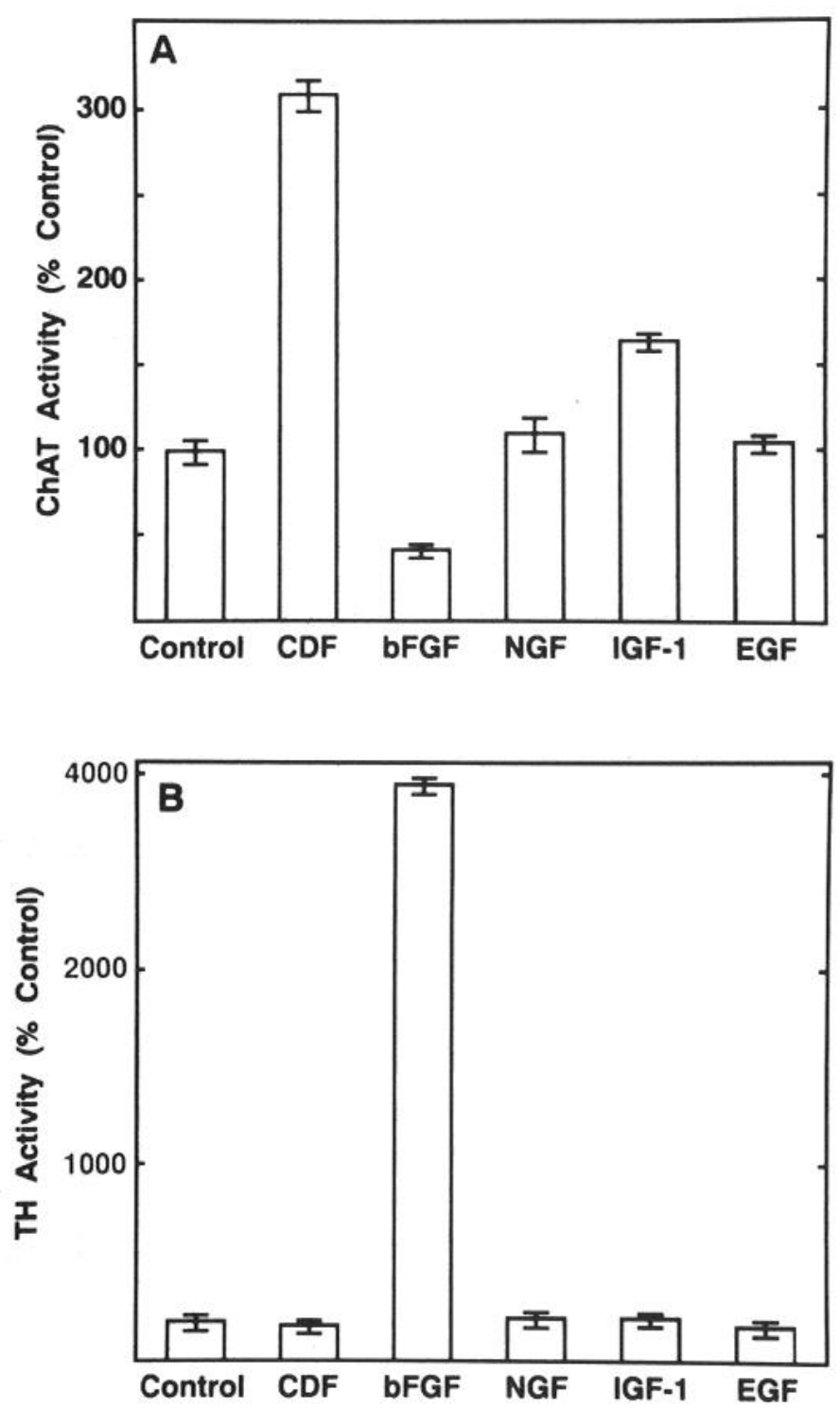

Figure 7. Differential effects of CDF, bFGF, NGF, IGF-I, and EGF on CAT and TH activity. IMR-32 cells were cultured in the presence of $5 \mathrm{~nm} \mathrm{CDF,} 3 \mathrm{~nm}$ bFGF, $20 \mathrm{~nm}$ NGF, $10 \mathrm{~nm}$ IGF-I, and 50 nм EGF or without factors for $6 \mathrm{~d}$. The effects of these treatments on CAT activity (CAT/well) $(A)$ and TH activity (TH/cell) $(B)$ are shown relative to control cells. Each value is the average \pm SD of triplicate culture wells.

CAT activity, and raise the possibility that bFGF may play a role in regulating the choice of neurotransmitter phenotype. bFGF has previously been shown to enhance CAT activity in cultures of rat spinal cord (McManaman et al., 1989), septal neurons (Knusel et al., 1990), ciliary ganglia (Vaca et al., 1989), PC-12 cells, and LA-N-2 cells (McManaman and Crawford, 1991). Thus, bFGF's effects on phenotypic properties appear to be variable and dependent on cell type.

Cell density has been shown to influence the induction CAT and/or TH in several different cell types (Edgar and Thoenen, 1978; Lucas et al., 1979; Acheson and Thoenen, 1983; Hefti et al., 1985b; Adler and Black, 1986; Kessler, 1986; Kirshner et al., 1986; Casper and Davies, 1988). Although the mechanisms of this effect are unknown, specific membrane proteins may mediate the density-dependent actions. For example, MANS has been shown to be involved in cell contact-mediated changes 
in cholinergic expression (Lombard-Golly et al., 1990). Our results show that although cell density does not by itself alter CAT or TH expression in IMR-32 cells, it does influence the effects of bFGF on TH expression. Furthermore, the effects of cell density on growth factor actions appear to be selective. In IMR-32 cells cell density does not influence the effects of either bFGF or CDF on CAT activity.

Previous reports have shown that bFGF can induce both proliferation and differentiation in several mesoderm- and neuroectoderm-derived cell types (Gospodarowicz et al., 1986). Stemple et al. (1988) have demonstrated that the effects of bFGF on proliferation and morphologic differentiation are distinct in PC-12 cells. We show that the effects of bFGF on phenotypic differentiation and proliferation are also distinct, since increases in TH levels are normalized to cell number, and there is increased immunofluorescent staining of individual IMR-32 cells after bFGF treatment. By contrast, CDF induction of CAT occurs in the absence of any effect on cell proliferation. These latter results are in agreement with previous studies demonstrating that CDF does not affect cell proliferation in either rat spinal cord cultures, mouse 3T3 fibroblasts, or human neuroblastoma cells (McManaman et al., 1988, 1989; McManaman and Crawford, 1991). Thus, in addition to their differential effects on phenotypic differentiation, CDF and bFGF actions differ with respect to induction of cell proliferation.

The effects of IGF-I, NGF, and EGF on neurotransmitter phenotype also appear to be selective. Only IGF-I specifically induces a modest increase in CAT activity, without affecting TH. Previous reports show that IGF-I can induce cell proliferation in the SH-SY5Y neuroblastoma cell line (Mattsson et al., 1986). In IMR-32 cells, however, IGF-I does not affect cell growth, suggesting that the increase in CAT activity occurs independently of these processes. Interestingly, there is no effect of NGF on neurotransmitter activity, even though it does stimulate the proliferation of these cells as shown here and in previous reports (Ludecke and Unsicker, 1990), as well as neuronal precursor cells (Cattaneo and McKay, 1990) and early developmental chromaffin cells (Lillien and Claude, 1985). The actions of NGF, therefore, need not be coupled to the expression of neurotransmitter enzymes. In contrast to the effects the other growth factors studied here, EGF had no effect on neurotransmitter phenotype or cell proliferation. Thus, our results suggest that a given growth factor may exhibit a diversity of actions on neurotransmitter development and that these actions are dependent on cell type and/or differentiation state of the cell.

\section{References}

Acheson AL, Thoenen H (1983) Cell contact-mediated regulation of tyrosine hydroxylase synthesis in cultured bovine adrenal chromaffin cells. J Cell Biol 97:925-928.

Adler JE, Black IB (1986) Membrane contact regulates transmitter phenotype expression. Dev Brain Res 30:237-241.

Adler JE, Schleifer LS, Black IB (1989) Partial purification and characterization of a membrane-derived factor regulating neurotransmitter phenotype expression. Proc Natl Acad Sci USA 86:1080-1083.

Barde Y-A, Edgar D, Thoenen H (1982) Purification of a new neurotrophic factor from mammalian brain. EMBO J 1:549-553.

Bostwick IR, Le W-D (1991) A tyrosine hydroxylase assay in microwells using coupled nonenzymatic decarboxylation of dopa. Anal Biochem, in press.

Carpenter G, Cohen S (1976) Human epidermal growth factor and the proliferation of human fibroblasts. J Cell Physiol 88:227-238.

Casper D, Davies P (1988) Regulation of choline acetyltransferase by cell density in a cultured human neuroblastoma cell line. Dev Neurosci 10:245-255.
Casper D, Davies P (1989) Mechanism of activation of choline acetyltransferase in a human neuroblastoma cell line. Brain Res 478:8594.

Cattaneo E, McKay R (1990) Proliferation and differentiation of neuronal stem cells regulated by nerve growth factor. Nature 347:762765.

Cavallito CI, Yun HS, Kaplan T, Smith JC, Foldes FF (1970) Choline acetyltransferase inhibitors: dimensional and substituent effects among styrypyridine analogs. J Med Chem 12:221-224.

Edgar DH, Thoenen H (1978) Selective enzymatic induction in a nerve growth factor-responsive pheochromocytoma cell line. Brain Res 154: 186-190.

Fonnum F (1969) Radiochemical micro-assays for the determination of choline acetyltransferase and acetylcholinesterase activities. Biochem J 115:465-472.

Goodman K, Slater E, Herschman HK (1980) Epidermal growth factor induces tyrosine hydroxylase in a clonal pheochromocytoma cell line, PC-G2. J Cell Biol 84:495-500.

Gospodarowicz D, Neufeld G, Schweigerer L (1986) Molecular and biological characterization of fibroblast growth factor, an angiogenic factor that also controls the proliferation and differentiation of mesoderm and neuroectoderm derived cells. Cell Differ 19:1-17.

Green LA, Ruckenstein E (1989) The quantitative bioassay of nerve growth factor with PC 12 cells. In: Nerve growth factors (Rush RA, ed), pp 139-147. New York: Wiley.

Hatanaka $\mathrm{H}$ (1981) Nerve growth factor-mediated stimulation of tyrosine hydroxylase activity in a clonal rat pheochromocytoma cell line. Brain Res 222:225-233.

Hefti F, Hartikka J, Eckenstein F, Ghahn H, Heumann R, Schwab M (1985a) Nerve growth factor increases choline acetyltransferase but not survival or fiber outgrowth of cultured fetal septal cholinergic neurons. Neuroscience 14:55-68.

Hefti F, Hartikka J, Frick W (1985b) Gangliosides alter morphology and growth of astrocytes and increase the activity of choline acetyltransferase in cultures or dissociated septal cells. J Neurosci 5:20862094.

Howard MJ, Bronner-Fraser M (1986) Neural tube-derived factors influence differentiation of neural crest cells in vitro: effects on activity of neurotransmitter biosynthetic enzymes. Dev Biol 117:45-54.

Kessler JA (1986) Developmental regulation of cholinergic and peptidergic development in rat striatum in culture. Dev Biol 113:77-89.

Kirshner JA, Markelonis GJ, Max SR (1986) Effects of cell division, cell density and cyclic nucleotides on choline acetyltransferase activity in a cholinergic neuroblastoma cell line (S-20Y). J Neurochem 46: 817-821.

Knusel B, Michel PP, Schwaber JS, Hefti F (1990) Selective and nonselective stimulation of central cholinergic and dopaminergic development in vitro by nerve growth factor, basic fibroblast growth factor, epidermal growth factor, insulin and the insulin-like growth factors I and II. J Neurosci 10:558-570.

Landis SC, Keefe D (1983) Evidence for neurotransmitter plasticity in vivo: developmental changes in propertics of cholincrgic sympathetic neurons. Dev Biol 98:349-372.

Lee KY, Seeley PJ, Muller TH, Helmer-Matyjek E, Sabban E, Goldstein M, Greene LA (1985) Regulation of tyrosine hydroxylase phosphorylation in PC12 pheochromocytoma cells by elevated $\mathrm{K}^{+}$and nerve growth factor. Mol Pharmacol 28:220-228.

Lewis EJ, Chikarishi DM (1987) Regulated expression of the tyrosine hydroxylase gene by epidermal growth factor. Mol Cell Biol 7:33323336.

Lillien LE, Claude P (1985) Nerve growth factor is a mitogen for cultured chromaffin cells. Nature 317:632-634.

Lombard-Golly D, Wong V, Kessler JA (1990) Regulation of cholinergic expression in cultured spinal cord neurons. Dev Biol 139:396406.

Lucas CA, Edgar D, Thoenen H (1979) Regulation of tyrosine hydroxylase and choline acetyltransferase activities by cell density in the PC12 rat pheochromocytoma clonal cell line. Exp Cell Res 121: 79-86.

Ludecke G, Unsicker K (1990) Mitogenic effects of neurotrophic factors on human IMR 32 neuroblastoma cells. Cancer 65:2270-2278.

Mattsson MEK, Enberg G, Ruusala A-I, Hall K, Pahlman S (1986) Mitogenic response of human SH-SY5Y neuroblastoma cells to insulin-like growth factor $I$ and II is dependent on the stage of differentiation. J Cell Biol 102:1949-1954. 
McManaman JL, Crawford FG (1991) Skeletal muscle proteins stimulatc cholinergic differentiation of human neuroblastoma cells. J Neurochem 57:258-266.

McManaman JL, Crawford FG, Stewart SS, Appel SH (1988) Purification of a skeletal muscle polypeptide that stimulates choline acetyltransferase activity in cultured spinal cord neurons. J Biol Chem 263:5890-5897.

McManaman JL, Crawford F, Clark R, Richker J, Fuller F (1989) Multiple neurotrophic factors from skeletal muscle: demonstration of effects of basic fibroblastic growth factor and comparisons with the 22-kilodalton choline acetyl transferase development factor. J Neurochem 53:1763-1771.

McManaman JL, Oppenheim RW, Prevette D, Marchetti D (1990) Rescue of motoneurons from cell death by a purified skeletal muscle polypeptide: effects of the CAT development factor, CDF. Neuron 4: 891-898.

Naujoks KW, Korsching S, Rohrer H, Thoenen H (1982) Nerve growth factor-mediated induction of tyrosine hydroxylase and neurite outgrowth in cultures of bovine adrenal chromaffin cells: dependence on developmental stage. Dev Biol 92:365-379.

Okuno S, Fujisawa $\mathrm{H}$ (1983) Assay of tyrosine 3-monooxygenase using the coupled nonezymatic decarboxylation of dopa. Anal Biochem 129:405-411.

Patterson PH (1978) Environmental determination of autonomic neurotransmitter functions. Annu Rev Neurosci 1:1-17.

Patterson PH, Chun LLY (1974) The influence of nonneuronal cells on catecholamine and acetylcholine synthesis and accumulation in cultures of dissociated sympathetic cultures. Proc Natl Acad Sci USA 71:3607-3610.

Pavelic K, Spaventi S (1987) Nerve growth factor (NGF) induced differentiation of human neuroblastoma cells. Int J Biochem 19:12371240.

Pollock JD, Krempin M, Kudy B (1990) Differential effects of NGF, FGF, EGF, cAMP, and dexamethasone on neurite outgrowth and sodium channel expression in PC12 cells. J Neurosci 10:2626-2637.

Prochiantz A, Daguet M-C, Herbet A, Glowinski J (1981) Specific stimulation of in vitro maturation of mesencephalic dopaminergic neurons by striatal membranes. Nature 293:570-572.

Rao MS, Landis SC, Patterson PH (1990) The cholinergic neuronal differentiation factor from heart cell conditioned medium is different from the cholinergic factors in sciatic nerve and spinal cord. Dev Biol 139:65-74.

Reynolds CP, Perez-Polo JR (1981) Induction of neurite outgrowth in the IMR-32 human neuroblastoma cell line by nerve growth factor. J Neurosci Res 6:319-325.

Rydel RE, Greene LA (1987) Acidic and basic fibroblast growth factors promote stable neurite outgrowth and neuronal differentiation in cultures of PC12 cells. J Neurosci 7:3639-3653.

Saadat S, Sendtner M, Rohrer H (1989) Ciliary neurotrophic factor induces cholinergic differentiation of rat sympathetic neurons in culture. J Cell Biol 108:1807-1816.

Schlesinger HR, Gerson JM, Moorhead PS, Maguire H, Hummeler K (1976) Establishment and characterization of human neuroblastoma cell lines. Cancer Res 36:3094-3100.
Schotzinger RJ, Landis SC (1990) Acquisition of cholinergic and peptidergic properties by sympathetic innervation of sweal glands requires interaction with normal target. Neuron 5:91-100.

Schubert D, Heinemann S, Kidokoro Y (1977) Cholinergic metabolism and synapse formation by a rat nerve cell line. Proc Natl Acad Sci USA 74:2579-2583.

Schubert D, Ling N, Baird A (1987) Multiple influences of a heparinbinding growth factor on neural development. J Cell Biol 104:635643.

Sonnenfeld KH, Ishii DN (1982) Nerve growth factor and receptors in cultured human neuroblastoma cell lines. J Neurosci Res 8:375391

Stemple DL, Mahanthappa NK, Anderson DJ (1988) Basic FGF induces neuronal differentiation, cell division, and NGF dependence in chromaffin cells: a sequence of events in sympathetic development. Neuron 1:517-525.

Stockli KA, Lottspeich F, Sendtner M, Masiakowski P, Carroll P, Gotz R, Lindholm D, Thoenen H (1989) Molecular cloning, expression and regional distribution of rat ciliary neurotrophic factor. Nature 342:920-923.

Swerts J-P, Thai AVL, Vigny A, Weber MJ (1983) Regulation of enzymes responsible for neurotransmitter synthesis and degradation in cultures rat sympathetic neurons. Dev Biol 100:1-11.

Thoenen H, Barde Y-A (1980) Physiology of nerve growth factor. Physiol Rev 60:1284-1314.

Thompson JM, London ED, Johnson JE (1982) Ultrastructural, functional and biochemical characteristics of mouse and human cell lines. Neuroscience 7:1807-1815.

Tomozawa Y, Appel SH (1986) Soluble striatal extracts enhance development of mesencephalic dopaminergic neurons in vitro. Brain Res 399:111-124.

Tumilowicz JJ, Nichols WW, Cholon JJ, Greene AE (1970) Definition of a continuous human cell line derived from neuroblastoma. Cancer Res 30:2110-2118.

Vaca K (1988) The development of cholinergic neurons. Brain Res Rev 13:261-286.

Vaca K, Stewart SS, Appel SH (1989) Identification of basic fibroblast growth factor as a cholinergic growth factor from human muscle. J Neurosci Res 23:55-63.

Vantini G, Schiavo N, Di Martino A, Polato P, Triban C, Callegaro L, Toffano G, Leon A (1989) Evidence for a physiological role of nerve growth factor in the central nervous system of neonatal rats. Neuron 3:267-273

West GJ, Uki J, Herschman HR, Seeger RC (1977) Adrenergic, cholinergic, and inactive human neuroblastoma cell lines with the action potential $\mathrm{Na}^{+}$ionophore. Cancer Res 7:1372-1376.

Xue ZG, Le Douarin NM, Smith J (1988) Insulin and insulin-like growth factors can trigger the differentiation of catecholaminergic precursors in cultures of dorsal root ganglia. Cell Differ Dev 25:1-10.

Yamamori T, Fukada K, Aebersold R, Korsching S, Fann M-J, Patterson PH (1989) The cholinergic neuronal differentiation factor from heart cells is identical to leukemia inhibitory factor. Science 246 1412-1416. 